\title{
"SIEMPRE HA ESTADO ATRAPADO EN MI INTERIOR PERO AHORA HA SALIDO": EXPLORACIONES DE LAS IDENTIDADES LINGÜÍSTICAS DE LOS NIÑOS A TRAVÉS DE ACTIVIDADES CREATIVAS.
}

\section{'IT'S ALWAYS BEEN STUCK INSIDE ME BUT NOW IT'S COME OUT': CHILDREN'S EXPLORATIONS OF THEIR LANGUAGE IDENTITIES THROUGH CREATIVE ACTIVITIES}

\author{
Ruth Levine \\ Lecturer in Education \\ Liverpool Hope University
}

Fecha de recepción: 12 de junio de 2013

Fecha de aceptación: 29 de junio de 2014

Fecha de publicación: 30 de junio de 2014

\section{RESUMEN}

¿Qué significa para los niños ser usuarios de diferentes lenguas? Una serie de actividades reflexivas y creativas se han desarrollado en un estudio doctoral reciente sobre las identidades lingüísticas de los niños, para ayudarles a explorar y articular sus identidades como hablantes de distintas lenguas. Los análisis de auto-representaciones explícitas de los niños en estas actividades establecieron que los individuos construyen, representan y negocian las identidades lingüísticas que pueden ser múltiples, cambiantes y a veces estar en tensión o contradicción. Por otra parte, las actividades utilizadas para la recolección de datos proporcionan un espacio en el que los niños exploran el uso de las lenguas dentro de sus diferentes comunidades y así aprenden a negociar sus múltiples y cambiantes identidades lingüísticas con mayor comprensión y confianza.

Palabras clave: Lenguaje; Identidad; Plurilingüismo; Bilingüismo; Metodología de Investigación; Actividades de clase.

\begin{abstract}
What does it mean to children to be users of different languages? A series of reflective and creative activities were developed in a recent doctoral study of children's language identities, to support children to explore and articulate their identities as users of different languages. Analysis of the children's explicit self-representations in these activities established that individuals construct, represent and negotiate language identities which may be multiple, shifting and sometimes in tension or contradiction. Furthermore, the activities used for data collection provide a navigational space in which children explore their use of languages within their different communities and so learn to negotiate their multiple and shifting language identities with greater understanding and confidence.
\end{abstract}

Key words: Language; Identity; Plurilingualism; Bilingualism; Research Methodology; Classroom activities. 
"Siempre ha estado atrapado en mi interior pero ahora ha salido": exploraciones de las identidades lingüísticas de los niños a través de actividades creativas.

\section{OBJECTIVES}

In the early $21^{\text {st }}$ century, a time of rapid social change and increasing cultural diversity in much of Europe, questions of social identity are at the fore in schools as in the wider society. The increasing heterogeneity of many communities in Europe is reflected in the growing number of languages spoken within these communities. In England more than 196 languages are now spoken outside London (e.g. Vidal Rodeiro, 2009). Schools in England reflect and are part of these social changes, and the increasing diversity is apparent in the increasing number of languages spoken by members of school communities. This has implications for the ways children understand and represent themselves and their place in school, in their local community and in the world. In light of the close relationship between individuals' language(s), identities and learning, a recent doctoral study (Levine, 2013) examined the ways a small sample of primary school children identified themselves as users of their different languages in linguistically diverse classes.

In this paper, the term 'language identity' refers to the claimed and/or ascribed relationships between individuals and their language(s). This draws on Block's (2006: 35) definition of language identity as 'the assumed and/or attributed relationship between oneself and a means of communication which might be known as a language (e.g. English), a dialect (e.g. Geordie) or a sociolect (e.g. footballspeak)'. This definition, however, keeps the focus on languages rather than language varieties, and leaves open the possibility that individuals may identify themselves as pluri- or multilinguals in addition to users of particular languages.

The overarching aim of the research was develop a detailed understanding of the ways nine children in two linguistically diverse primary schools in the UK explicitly identified themselves as users of their different languages and how they represented and negotiated their language identities in interactions in the foreign language classroom. The findings were drawn together in a preliminary model of children's language identity (Levine, 2013). The objective of an early analysis in the larger study was to establish whether children's explicit representations of their language identities could be meaningfully researched from a poststructuralist perspective. This is the focus of this paper. As poststructuralist thinking values fragmentation, fluidity, contradiction and context, it is fitting that there should be no fixed, consistent and unitary poststructuralist conceptualisation of identity (Block, 2007b). Poststructuralist research into identity varies in the degree of emphasis on the ways individuals' identities are shaped by their biographies, and 
deeply situated in their social, cultural and historical contexts; on the ways individuals position themselves and are positioned by others in social interactions and in relation to past and present experiences and to hopes, expectations and fears for the future. Recognising that social structures, often relating to demographic categories such as age, gender, ethnicity and race, constrain the ways individuals identify themselves, some poststructuralist research focuses on unequal power relations while other studies examine individuals' demonstrations of agency in ongoing, self-conscious acts of self-identification (e.g. Block, 2007a and b; Norton and Toohey, 2011). However, Weedon's foundational writing (1987) nonetheless established certain broad principles: poststructuralists conceptualise identity not as the essential, stable core of the self but as 1) multiple; 2) shifting over historical time and social space; and 3) a site of struggle as individuals wrestle with tensions and contradictions. This study takes these three fundamental principles as its definition of a poststructuralist approach to identity.

There has been extensive poststructuralist research interest in the subject positions that individuals take up in relation to the wellrecognised identity categories of gender, social class, race, ethnicity and national identity, and sexual orientation. Language identity is much less well known as a social identity, and there is a dearth of studies into language identity. It was anticipated that taking a poststructuralist perspective on children's language identities would provide the data needed to build a detailed understanding of the children's language identities. At the beginning of the study, though, it was not clear whether primary school children would identify themselves in relation to their languages in multiple and shifting ways, or whether their languages identities would be a site of struggle. This paper reports on early findings in the study that demonstrate that children's explicit representations of their language identities can be meaningfully researched from a poststructuralist perspective.

\section{METHODOLOGY}

The objective of establishing whether children's explicit representations language identities could be meaningfully researched from a poststructuralist perspective had implications for the research methodology: rather than looking to uncover the children's 'real' language identities, the study set out to explore how the children represented and negotiated their subject positions as users of languages, whether these self-representations shifted over time and social space, and whether children expressed tensions or contradictions in relation to their languages. 
"Siempre ha estado atrapado en mi interior pero ahora ha salido": exploraciones de las identidades lingüísticas de los niños a través de actividades creativas.

Establishing whether children's explicit representations of their language identities can be meaningfully researched from a poststructuralist perspective required a nuanced, qualitative approach because it was anticipated that the interest of the study may lie in the complex interplay between the children's language identities as they hold multiple identities together and sometimes in tension, and as different dimensions of their identities are sometimes salient and foregrounded and sometimes hidden or even denied. To 'average out' the differences (Dornyei, 2007) through quantitative enquiry would have masked the very different ways the children perceived and positioned themselves in relation to each of their languages, and into the ways their language identities shifted across time and social space.

The research was designed as a multiple case study (Stake, 1995) to support an in-depth examination of the ways the children identified themselves as users of different languages over the course of the school year. In line with Van Lier (2005) and Dornyei (2007), who assert that case studies can provide unparalleled insight into shifts over time in complex phenomena, the continuities and contradictions, changes and developments in the ways the children identified themselves at different points in the school year were of compelling interest in this study.

Participants were selected for 'potential for learning' (Stake, 1998) not representativeness. Nine children (aged ten and eleven years) were selected from two primary schools in a city in South East England. The children came with a wide range of home language profiles: they spoke different languages; they had been resident in the UK for different lengths of time; three of the children used faith languages. The relevant details about the children's languages are summarised in the table below:

\begin{tabular}{|c|c|c|c|c|}
\hline $\begin{array}{l}\text { Child's } \\
\text { name }\end{array}$ & $\begin{array}{l}\text { Languages } \\
\text { spoken in the } \\
\text { home }\end{array}$ & Where lived & $\begin{array}{c}\text { Other } \\
\text { languages } \\
\text { used }\end{array}$ & $\begin{array}{l}\text { Languages learnt in } \\
\text { lessons }\end{array}$ \\
\hline Amber & $\begin{array}{l}\text { English (father's } \\
\text { first language) } \\
\text { German } \\
\text { (mother's first } \\
\text { language) }\end{array}$ & UK & & $\begin{array}{l}\text { French in school } \\
\text { Used to learn Italian in } \\
\text { extracurricular club }\end{array}$ \\
\hline Harunobu & Japanese & $\begin{array}{l}\text { In Japan aged } \\
0-5 \text {; lived in } \\
\text { UK since }\end{array}$ & English & French in school \\
\hline Katya & Russian & UK & English & $\begin{array}{l}\text { Russian in weekly } \\
\text { Russian school } \\
\text { French in school }\end{array}$ \\
\hline
\end{tabular}




\begin{tabular}{|c|c|c|c|c|}
\hline $\begin{array}{l}\text { Child's } \\
\text { name }\end{array}$ & $\begin{array}{l}\text { Languages } \\
\text { spoken in the } \\
\text { home }\end{array}$ & Where lived & $\begin{array}{l}\text { Other } \\
\text { languages } \\
\text { used }\end{array}$ & $\begin{array}{l}\text { Languages learnt in } \\
\text { lessons }\end{array}$ \\
\hline Lizzie & English & UK & & \\
\hline Pedro & $\begin{array}{l}\text { English } \\
\text { German } \\
\text { (father's first } \\
\text { language) } \\
\text { Spanish } \\
\text { (mother's first } \\
\text { language) }\end{array}$ & UK & & $\begin{array}{l}\text { French in school } \\
\text { Used to learn Spanish in } \\
\text { extracurricular club }\end{array}$ \\
\hline Anuradha & $\begin{array}{l}\text { English } \\
\text { Urdu }\end{array}$ & $\begin{array}{l}\text { In Pakistan } \\
\text { aged 0-5 and } \\
7-8 ; \text { in UK } \\
\text { aged 5-7 and } \\
8-11\end{array}$ & & $\begin{array}{l}\text { French in school } \\
\text { Learning a little Italian } \\
\text { from father who lives in } \\
\text { Rome }\end{array}$ \\
\hline Fadhiya & $\begin{array}{l}\text { Bangla } \\
\text { English }\end{array}$ & UK & $\begin{array}{l}\text { Sign } \\
\text { Language } \\
\text { with uncle } \\
\text { who } \\
\text { is deaf and } \\
\text { Arabic in } \\
\text { religious } \\
\text { practices }\end{array}$ & $\begin{array}{l}\text { Arabic lessons } \\
\text { at mosque three } \\
\text { times a week } \\
\text { Bangla lessons } \\
\text { at mosque once } \\
\text { a week } \\
\text { French in school } \\
\text { Sign Language in } \\
\text { extracurricular lessons } \\
\text { Used to learn Italian in } \\
\text { school }\end{array}$ \\
\hline Mark & English & UK & & $\begin{array}{l}\text { French in school } \\
\text { Latin in extracurricular } \\
\text { club } \\
\text { Used to learn Italian in } \\
\text { school }\end{array}$ \\
\hline Zax & $\begin{array}{l}\text { English (father's } \\
\text { first language) } \\
\text { Polish (mother's } \\
\text { first language) }\end{array}$ & $\begin{array}{l}\text { Born in UK } \\
\text { but lived in } \\
\text { Poland Until } \\
\text { aged } 9 \text { then } \\
\text { moved to UK }\end{array}$ & $\begin{array}{l}\text { Hebrew in } \\
\text { religious } \\
\text { practices }\end{array}$ & $\begin{array}{l}\text { Hebrew lessons } \\
\text { in preparation } \\
\text { for bar mitzvah } \\
\text { Private lessons } \\
\text { in German } \\
\text { French in school }\end{array}$ \\
\hline
\end{tabular}

The names given are pseudonyms chosen by the children from the same language as their real names.

The primary schools were also selected for linguistic diversity of the pupils: in each school $35-40 \%$ of the pupils spoke languages in addition 
to English, and at least 10 languages were spoken by pupils in each of the four classes in the sample. Both schools taught a foreign language from Year 3 (when the pupils are seven years old).

A 'mosaic approach' (Clark and Moss, 2001) was taken to gathering data for the wider doctoral study. Several data collection tools were used to build up a rounded picture of the ways the children identified themselves as users of languages explicitly and implicitly: reflective and creative activities with the children; interviews with their teachers; observations of the children in foreign language lessons; and recordings of the children in intervention lessons. This paper focuses on the series of reflective and imaginative activities which supported the children to explore and articulate their language identities. These activities were developed to elicit from the children explicit representations of themselves as users of languages.

\section{DATA COLLECTION}

Eliciting explicit representations of their language identities from the children presented a number of challenges. The children participating in the research were ten and eleven year-olds and may well never have given any thought to their language identities prior to the study. Questioning them directly was unlikely to yield rich and detailed data. Furthermore, in this grounded study it was important that the activities should be non-directive, engaging the children's selfunderstandings and not introducing pre-existing concepts from the literature.

The children's explicit self-representations were elicited through a range of activities which encouraged the children to explore and articulate what being a speaker of different languages meant to them. At first the activities were straightforward and relatively concrete so that the children could talk about their languages with confidence; more abstract and open-ended activities were used towards the end of the year. The activities are described below with quotations from the children as they were engaged in the activities illustrating how the activities enabled the children to explore and voice their identities as users of languages. 


\section{Activity 1. Languages mind-maps.}

The first activity was a mind-map of the children's languages. The children indicated the languages they used, where they used them and with whom, and also noted if they knew a few words of other languages in a box in a corner of the page. The children then explained their mind-maps to the researcher. In doing so, they spoke about their language biographies, the languages spoken in the home, the faith contexts in which certain languages were used, and where and when the children had started learning their different languages. The example below presents Anuradha's mind-map of her languages and her explanation:

\section{'My first language that was Urdu. I used to be very good at Urdu but [...]. now that l've been living here for a long time I know less Urdu. [...] I speak Urdu when I'm at home [in Pakistan] talking with my family cos all my family keeps on nagging at me to speak even more.'}

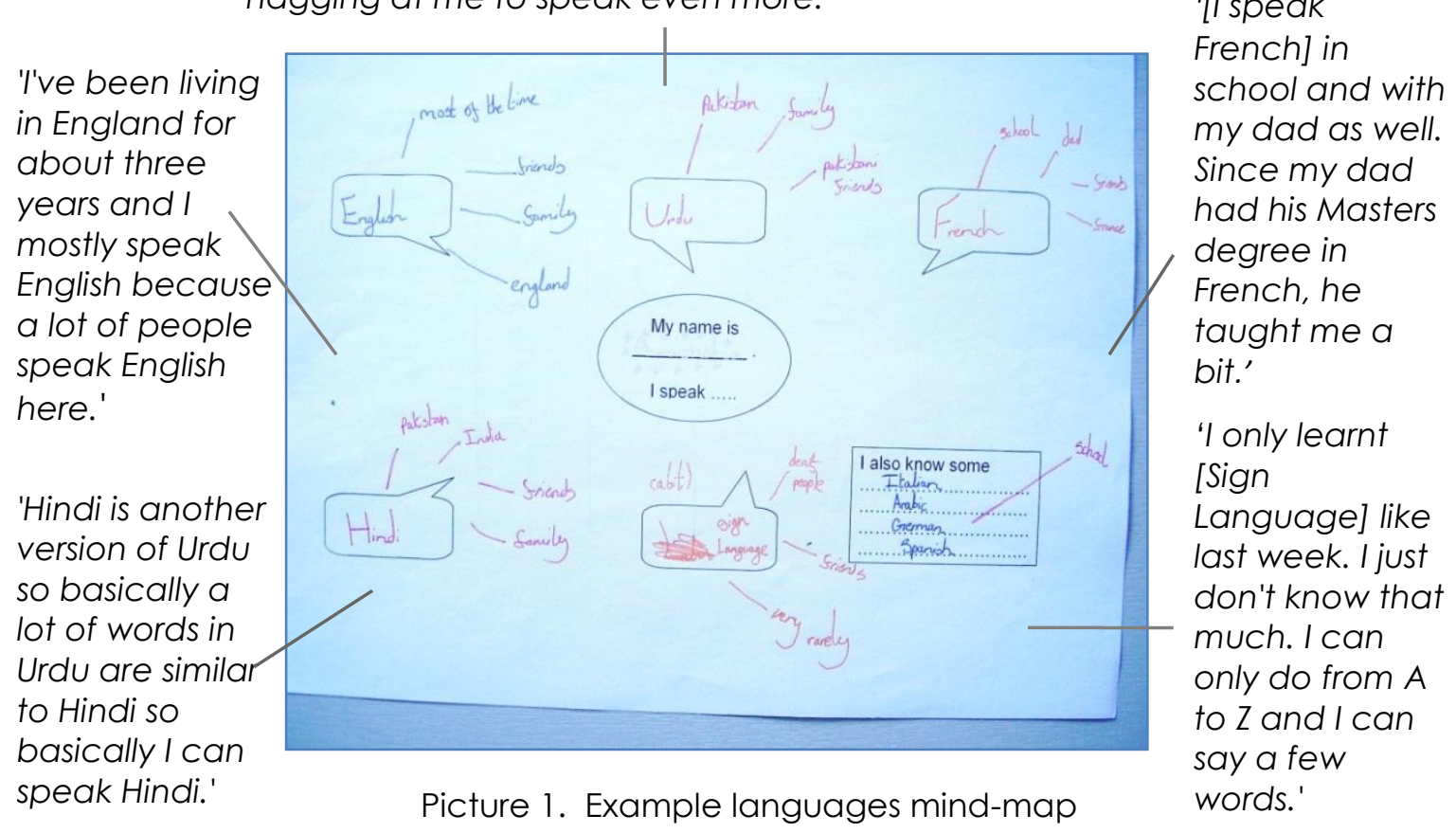

\section{Activity 2. Languages flags}

In the second activity, the children drew flags to represent their languages and then to explain their flags to the researcher. They were prompted with questions, for example about the size of the blocks representing their different languages and the positions of the languages on the flag. The example below presents Harunobu's flag and his explanation: 
"Siempre ha estado atrapado en mi interior pero ahora ha salido": exploraciones de las identidades lingüísticas de los niños a través de actividades creativas.

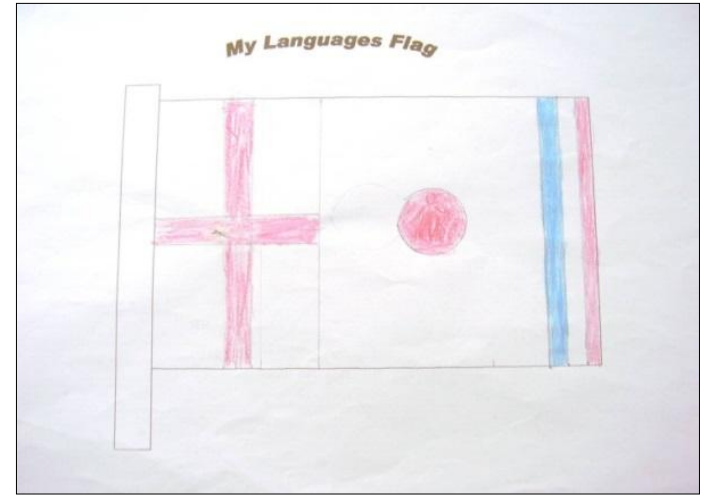

Picture 2: Example languages flag
'I'm really proud about my Japanese. [...] My parents and stuff are Japanese and so this is most of [the flag], but I have been in England for most of my life so that was the second largest and French l've done just a bit so it's quite small. [...] I'm Japanese and I live in England and I speak England most of the time and French I just learn it. So it goes in that way.'

\section{Activity 3. 'Jelly baby tree'.}

The children were given pictures of a 'jelly baby tree' (see below) and asked to identify figures to represent themselves as users of each of their languages and to explain their choices. The children were encouraged to look at the different figures on the tree and to note their positions and moods and that some were on their own while others with in pairs or groups, before being asked to identify themselves as users of languages with particular figures. Picture 3 indicates the figures Fadhiya selected to represent herself as a user of her different languages. It should be noted that she stopped learning Italian two years before taking part in this activity.

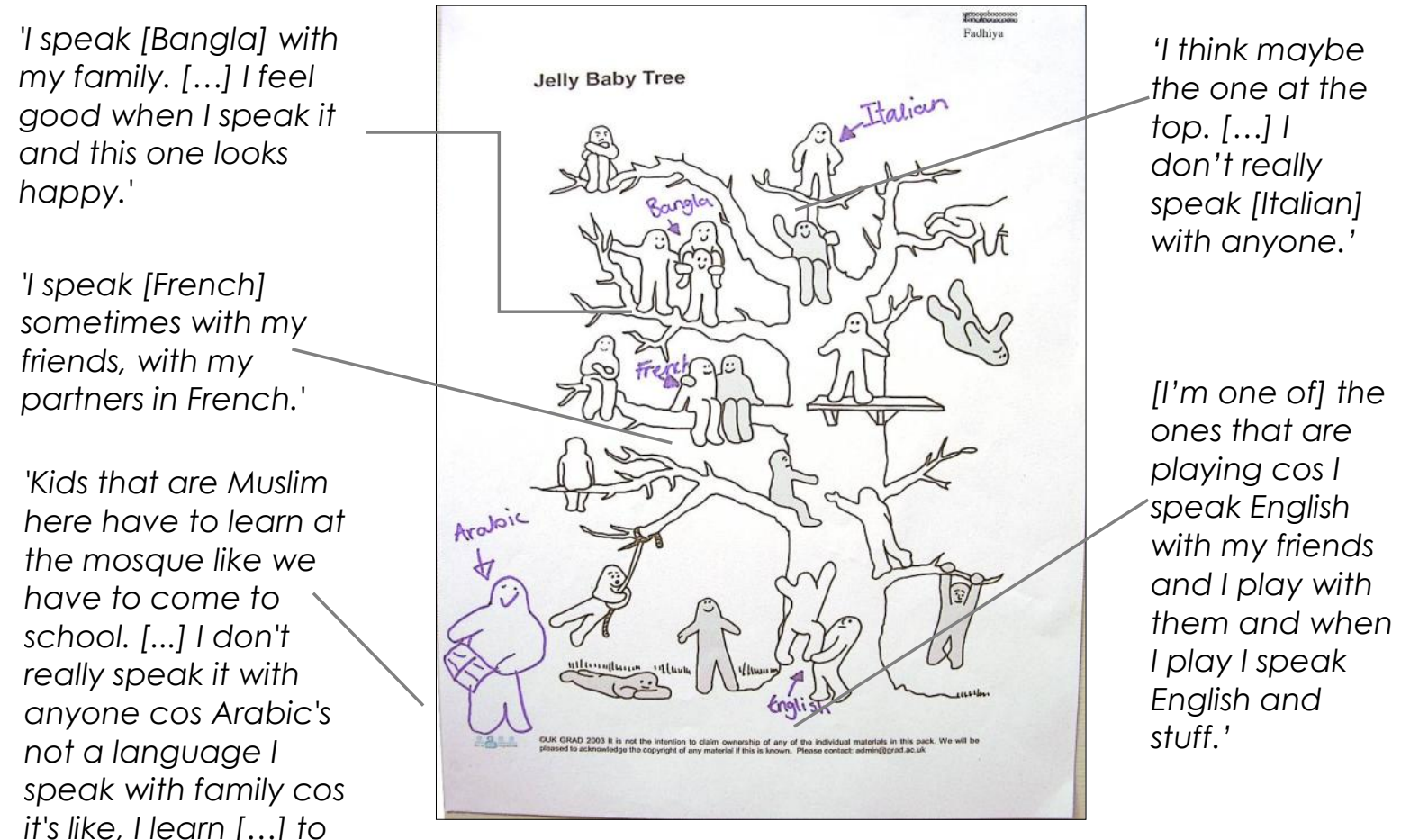
it's like, I learn [...] to read it.'
Picture 3. Example 'jelly baby tree'. 


\section{Activity 4: Drawing trees}

This next activity provided a means of asking probing questions about their perceptions of themselves as users of different languages whilst still taking care not to introduce pre-understandings. It was adapted from a technique Oaklander (1978) developed in a therapeutic context. Oaklander encouraged children with social and behavioural problems to draw themselves as rose-bushes and to explain their pictures aloud. Adapting this, the children were invited to imagine that they were a different tree when they spoke each of their languages and were asked the following questions:

'What sort of tree are you? How old are you? What are your leaves like? How old is the tree? How deep do your roots go? Do you get all the water and sunlight you need? Where are you? Is there a fence around you or an open place? What's the weather like? Are there other trees around? What's going to happen to this tree in the future?'

The children then drew the imagined trees in turn. They explained their pictures either while they were sketching or afterwards. The use of metaphor in this way enabled searching questions to be posed whilst always working with children's self-understandings as the children interpreted the metaphors in ways they considered meaningful.

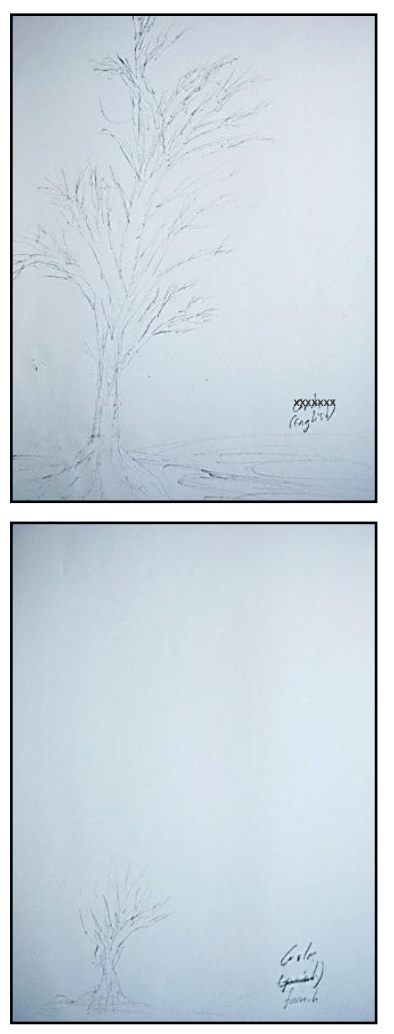

It's got pretty deep roots because, well, I feel l've had lots of opportunities to get better at English. [...] It's a pretty big tree because I feel like I've done pretty well at learning English. [...] And there's lots of branches because I've branched out to think of new things. [...] But I don't think it's fully grown yet because I've still got a lot of life to learn about new things.'

IIt's a healthy tree because I do French lessons every week and that helps. It's not the biggest tree, but as we've only been doing French for two years, it's grown quickly to the size it is now. Its branches are spreading but they haven't spread everywhere yet because I haven't learnt everything. There's still a lot more to go. I like being this tree because I'm like satisfied with what I've done. It's in a park because in the class everyone else is learning French as well, so there are lots of people, lots of trees there.' 

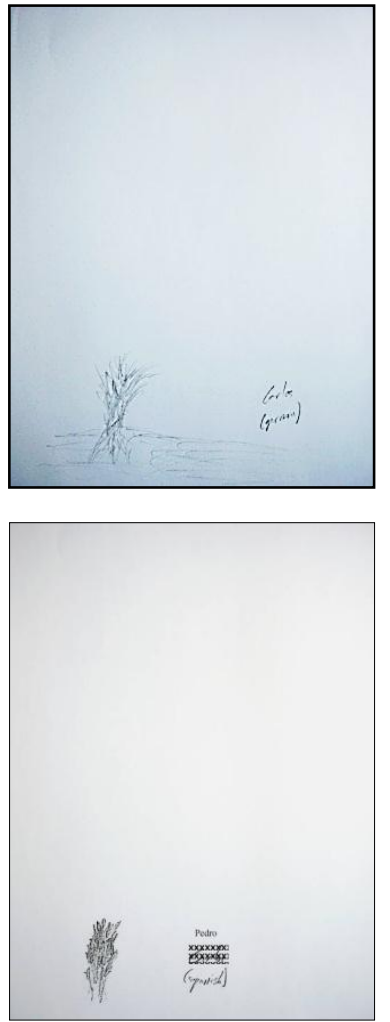

'It's a small shrub. [...] I haven't learnt that much of German. It's not totally healthy cos I don't have that many opportunities to learn German. I don't really have lessons and I don't go forward a lot. [...] I want to get better but I'm sort of stuck at one place. [...] But it's got good roots because my father's German. Later on it will grow bigger and better. In secondary school, I probably am going to try to do German. But at the moment, when it's young, it's just small.'

'I haven't really done anything with Spanish for a long time so it's sort of wilting. [...] Because I don't do any lessons with it, I keep going backwards because I forget words. [...] I could have put a bit more effort in learning it and I should have. [...] I'm going to try to do some Spanish in secondary school but I don't know if that will work out. [...] [My mother will] like it a lot and be proud because she's always wanted me to learn Spanish because that's her native language. [...] This tree has] got good roots because my family [speaks Spanish].'

Pictures 4. Examples of drawings of trees.

\section{Activity 5: 'My Colourful Languages'}

The children wrote poems about themselves as users of different languages using colours as a stimulus. Having first talked about how colours might be associated with objects, places, feelings etc., the children were encouraged in free association, for example linking white with snow, red with anger, green with nature. The children were then asked what colour they were when they used each of their languages and what colour they hoped to become. After discussing their ideas, the children wrote them up as poems. The children were invited to finish their poems with an image which conveyed how they saw themselves as users of all their languages. The poem below was written by one of the participants, Katya. The spelling and grammar are left unchanged. The comments added are taken from Katya's explanation of her poem. 


\begin{tabular}{|c|c|c|}
\hline $\begin{array}{l}\text { 'Red is a very } \\
\text { confident colour. I } \\
\text { feel most confident } \\
\text { in English because } \\
\text { I've talked it for } \\
\text { most of my life. I } \\
\text { was born in } \\
\text { England; I grew up } \\
\text { in England; I live in } \\
\text { England. Most of my } \\
\text { friends are English } \\
\text { and, actually, I } \\
\text { speak English with } \\
\text { some of my Russian } \\
\text { friends too.' } \\
\text { 'The blue is getting } \\
\text { darker as I learn } \\
\text { more. I'm just a } \\
\text { beginner but I am } \\
\text { learning. I'll keep } \\
\text { getting better at } \\
\text { French at } \\
\text { secondary school.' }\end{array}$ & $\begin{array}{l}\text { LANGUAGE FLOWER } \\
\text { When I speak English I feel } \\
\text { confident, and to me the most confident } \\
\text { coulor is red. } \\
\text { When I speak Russian I'm rosy and } \\
\text { pink because I fell warm and soft. And } \\
\text { light green which will become darker in } \\
\text { dew time. } \\
\text { When I speak French I'm light blue } \\
\text { (for now) but will soon get darker and } \\
\text { better at it. } \\
\text { And when I speak Spanish I feel } \\
\text { like oranges that grow on trees in the } \\
\text { fields! And yellow because I } \\
\text { don't know much of the } \\
\text { language. } \\
\text { The russian tale of a coulorful } \\
\text { flower which had a wish for every petal is } \\
\text { the flower that I think of when I put all my } \\
\text { languages together because I also have } \\
\text { a wish for every language to either get } \\
\text { better at it or learn more. }\end{array}$ & $\begin{array}{l}\text { 'Yellow is the } \\
\text { colour of sunshine } \\
\text { and the beach. } \\
\text { My auntie has a } \\
\text { flat in Spain by the } \\
\text { sea. We go there } \\
\text { quite often in } \\
\text { summer and I } \\
\text { really like it so I } \\
\text { want to learn } \\
\text { Spanish at } \\
\text { secondary school.' }\end{array}$ \\
\hline
\end{tabular}

'In Russia for young children there's a tale of a flower that a little girl gets given and she has a wish for every petal and it's a multicoloured flower. [...] [The petals] were different colours. [...] It has a wish for every petal and I have wishes to get better at languages and to learn more about them and the countries that speak them, so I also have wishes on every petal of every colour of every language.'

Picture 5. Example of a 'My Colourful Languages' Poem.

Please note that the poem has been copied as Katya wrote it and so the orthography has not been corrected. 
"Siempre ha estado atrapado en mi interior pero ahora ha salido": exploraciones de las identidades lingüísticas de los niños a través de actividades creativas.

\section{DATA ANALYSIS}

Each time I gathered data through the stimulus activities with the children, I wrote a short narrative analysis for each child. I identified key themes in the data and then, after the first episode of data collection, reflected on how this new data related to the understanding of the child I had developed on previous occasions. I considered whether it affirmed my prior perceptions of a child's language identities, provided additional insights, or pushed me to review my understanding. This highlighted continuities and contradictions, developments and changes in the children's self-representations over time. Understanding that as stories are told and retold, their meanings shift, I noted when I felt the children were 'restorying' earlier experiences in the light of later experiences (Connelly and Clandinen, 1990). It could be argued that the authority and stability of interpretation are brought into question if new rounds of data threaten to render previous interpretations redundant (Dornyei, 2007). In this analysis, shifting representations were the centre of interest. Rather than seeking convergence in a singular understanding of the children's language identities, I sought to make sense of multiple, shifting identities. I noted points where the children's self-representations shifted and where my understandings evolved, as well as my uncertainties and questions about the children's language identities. In this way I built up a profile of each child's language identities drawing on all the strands of data. Through gaining a detailed, contextualised understanding of each child's language identities, I recognised and made sense of the shifts, tensions and complexities in the children's language identities. In summary this line of analysis for each child in the sample included:

- the compilation of a brief language profile including the languages spoken in family, the child's language biography and use of languages (as reported by the child);

- the identification of themes in the child's explicit selfrepresentations in each of the activities;

- the noting of points which particularly interested or puzzled (reflections/questions);

- the tabulation of themes in self-representations across the school year;

- the identification of points of continuity and shifts in child's explicit self-representations in the different activities;

- a summary interpretation of points of continuity and change.

Writing narrative analyses was a fitting method of data analysis as I sought to understand the ways the children identified themselves as users of their different languages in the light of their unique personal histories and social contexts, and was keen to avoid reducing the data 
to a list of themes. Through writing and rewriting, I made discoveries about the data and clarified my perceptions of the children (Charmaz, 1990). With experience in using NVivo in another project, I had assumed I would use it in this study too. However, when I began to analyse the data with NVivo, I found it unhelpful: it 'broke down' the data into categories whereas the interest in the data lay in the connections between the ways the children identified themselves and their language-related experiences and the social and linguistic contexts in which they constructed and enacted their identities. Instead, writing and rewriting enabled me to take a holistic perspective, perceiving continuities in the ways some children identified themselves and their languages in diverse social contexts and exploring the complexities and contradictions in the data relating to the other children to make sense of the tensions they experienced as users of different languages.

\section{RESULTS}

This section of the paper evaluates the effectiveness of the activities in providing rich and detailed data relating to the varied and shifting ways the children identified themselves explicitly in relation to their languages. The study was designed in the expectation that children's language identities could be most meaningfully explored by building on broadly post-structuralist insights into identity. The following paragraphs evaluate the effectiveness of the activities as a tool for eliciting the children's explicit representations of themselves in relation to each of their languages in the light of the broad post-structuralist understanding that individuals construct, represent and negotiate identities which may be multiple, shifting and sometimes in tension, as outlined in Weedon's foundational study (1987).

The aim was not to obtain an objective statement of how the children 'really' saw themselves as users of different languages. Rather, it was to explore alongside the children the meanings they attributed to their languages though listening, questioning, and seeking insights into the different ways the children identified themselves over time. In representing their language identities explicitly through these activities, the children were not relaying facts about themselves as users of languages, but positioning and repositioning themselves in relation to their languages in the context of the research relationship and interactions.

The activities supported the children in the study to explore and represent multiple language identities. All the children depicted themselves as users of English in the school and local community and 
"Siempre ha estado atrapado en mi interior pero ahora ha salido": exploraciones de las identidades lingüísticas de los niños a través de actividades creativas.

as learners of French in the classroom, and all but two represented themselves as users of additional languages in their families and communities outside school. The children's explicit self-representations brought to the fore the different ways they identified themselves in relation to each of their languages. As can be seen in the children's comments cited above, they expressed different levels of confidence in their languages. Pedro, for example, drew his trees different sizes to indicate his level of proficiency in his languages. The children also related their use of particular languages to wide-ranging social affiliations, in particular family, national identities and faith communities. Fadhiya, for example, associated speaking Bangla with her family, Arabic with her faith, English with her school friends and French with her class. Harunobu related speaking Japanese to his national identity as well as his family. The children were constructing their multiple language identities in the context of the social identities which they associated with their languages. Katya expressed this with particular insight: 'Sometimes I feel more confident with English but sometimes I feel more confident with Russian because we're both Russian and we understand each other as Russian people and English people.'

Eliciting the children's explicit self-representations through the activities on different occasions over the school year made it apparent that the children did not represent their language identities in fixed and stable ways. Their self-representations shifted over time. Perhaps not surprisingly the children expressed changing levels of confidence in both home and foreign languages. For example, Anuradha initially expressed concern at her perceived loss of proficiency in Urdu: 'I don't want to be better at [English] than Urdu because I don't want my family to think I'm more British than Pakistani'. Later in the year, following a visit to Pakistan, she commented: 'I'm fine with how I feel when I speak [English and Urdu] right now. I don't think they can get any better.' Pedro described his increasing competence in French, the foreign language he was learning in school but his confidence in his proficiency in Spanish (his mother's language) decreased over the year. At the beginning of the year he described himself as 'forgetting words' and at the end of the year, Pedro stated: 'I don't really remember anything'.

The children's self-representations in the activities also brought to the fore shifts in the social affiliations they voiced in relation to particular languages. At times the changes in the children's selfrepresentations pointed to the children's implicit understanding that one language could relate to several aspects of their social identity; on different occasions Anuradha, for example, associated speaking Urdu 
with her family, and with her identity as a Pakistani and as a Muslim. Other shifts in the children's self-representations indicated that some of the children were developing visions of themselves using their home and foreign languages in new ways in the future. For example, during the year Pedro moved from articulating his aspirations for German only in terms of increased competence to wanting to interact meaningfully with people when visiting Germany. Similarly, at the end of the year of data collection, Katya voiced an ambition to improve her Russian so that she might spend a year living independently in Russia and a growing integrative motivation for learning foreign languages. She explained she aspired to learn Spanish so that she might study there for a year and that learning about French culture had stimulated her interest in Francophone countries and that she wanted to learn French partly so she could travel around Canada.

The children's self-representations elicited through the activities brought into focus tensions and contradictions the children experienced in relation to their languages. For example, Anuradha represented herself as becoming less proficient in Urdu while living in the UK. She jokingly bemoaned her relatives 'nagging' her to use Urdu more often and 'teasing' her for speaking Urdu with an English accent, but struggled with the thought that they might interpret her decline in proficiency in Urdu as a sign of her becoming 'more British than Pakistani'. The contradictions were particularly pronounced in Pedro's self-representations. He talked about his Spanish and German 'roots' but later vehemently denied that he knew his parents' languages ('Just because your parents are something doesn't mean you are') and asserted his identity as 'an English boy'. Pedro viewed speaking English as 'normal' and did not want to be different from his peers.

\section{CONCLUSION}

To conclude, the evaluation of the activities as a data collection tool illustrates that through these activities the children were supported to explore and articulate their language identities. The children's selfrepresentations enabled their language identities to be analysed in their multiplicity, their instability and their tension, consistent with the broadly post-structuralist understanding of identity which underpins the study. One of the challenges in making sense of this data was to interpret the shifts, tensions and contradictions in the children's selfrepresentations in a discerning way since they did not always reflect an underlying change or struggle in the children's self-perceptions. The changes in the children's self-representations sometimes related to a particular activity and sometimes to the developing trust established 
"Siempre ha estado atrapado en mi interior pero ahora ha salido": exploraciones de las identidades lingüísticas de los niños a través de actividades creativas.

between the children and the researcher. Also, shifts in the children's self-representations sometimes reflected a deeper engagement with particular dimensions of themselves through the activities. This will be discussed in the final part of this paper.

\section{DISCUSSION: THE VALUE OF THESE ACTIVITIES IN THE CLASSROOM}

Imaginative and reflective activities such as those used for data collection in this study can provide a 'navigational space' (Moje et al., 2004) in which children explore their use of languages within their different communities and so learn to negotiate their multiple and shifting language identities with greater understanding and confidence. This is the focus of this final section of the paper, which reflects on the children's comments about their experiences of taking part in the activities used for data collection in this study, and on the shifts in the children's representations of their language identities in the course of these activities.

Through the activities detailed in this paper, children who may never have given any thought to their language identities were supported to explore and articulate what being a user of different languages meant to them. It should be emphasised that the activities were designed as a data collection tool to elicit the children's explicit self-representations, not to help the children. Whilst care had been taken to conduct the data collection in a sensitive and ethical way, it was a pleasant surprise when, during the debrief at the end of the year, each of the children independently commented that the activities had helped them to understand themselves and their languages in new ways.

The children all commented that they rarely talked about their languages with other people and that they found it helpful to do so through the activities. Katya described her experience of the activities in terms of 'opening up' a dimension of her life which she usually kept unexpressed:

'You can tell someone about it and you can actually just think about it yourself for a while cos it's always been stuck inside me but now it's kind come out and I have a chance to think about it. [...] Just kind of having a task like [the poem] to do about feelings for my languages [helped me] because [...] it opened up feelings.'

Pedro and Anuradha commented that they came to a better understanding of themselves and their languages better because the 
activities required them to think about their languages and put this into words. Pedro explained that the activities had helped him understand himself better 'because in each meeting [he needed] to think about what to say and how [he could] express [his] feelings about the languages.' Anuradha expressed her new confidence in talking about her language identities:

'Everything we've done actually helped me learn about my own languages cos before I met you I didn't really know about myself and my languages. [...] Now I feel a bit more confident when we talk about languages. Before I didn't really know what to say but now that we've talked about it a lot I know what to say.'

The children valued the opportunity to think and talk about themselves and their languages, and came to understand themselves through the activities.

Some children identified specific ways in which the activities had helped them with their language identities, commenting on new understandings relating to their confidence in different languages, and of the social affiliations associated with their languages. Pedro commented that drawing trees to represent himself as a user of different languages helped him to make sense of how his proficiency in different languages had changed over time. Katya noted that certain activities had helped her to take a future perspective on their languages. She remarked that writing a poem using colours to stimulate thought about her languages encouraged her to consider 'what [she needed] to do to make them better'. Anuradha and Katya spoke at some length about how the activities had helped them understand the relationship between their languages and social affiliations. Anuradha explained that she had come to understand how her different languages enabled her to feel at home in a number of different countries: 'I realised how important it is that I have so many languages so if I travel to a part of the world I won't feel like an outsider.' Katya described feeling more at ease having thought about the significance of being speaking Russian and English and participating in the two cultures she associated with these languages:

'It makes me feel more comfortable knowing how the languages change my life cos Russian changes my life quite a lot. [...] Just talking English all the time outside my home but Russian inside my home makes quite a difference to me. [...] It's a different language, a different life, really. It's just so different. Different food, different reactions sometimes.' 
Shifts in the children's self-representations over the year of data collection also indicate the potential benefits of such activities. The activities supported Pedro to articulate the tensions he experienced in relation to his home languages, and through doing so, he was able to reflect on these and come to new understandings: he realised that he would have opportunities to improve his German at secondary school, and glimpsed the importance of German to him in terms of both family history and future social opportunities. Pedro moved from only expressing frustration with his slow progress with German to envisaging spending time in Germany and interacting meaningfully in the language. In a very different way, the activities encouraged other children to consider how foreign languages might feature in their lives. Over the course of the year, Katya began to articulate a nascent vision of themselves as a user of French, the foreign language she was learning in school. She described being motivated to learn French so she could travel in Canada and voiced a developing aspiration to speak Spanish: 'I'd like to go to Spain for a while and try to make some friends out there [...] [Go to] university or something'. Anuradha, facing an imminent move to Rome, voiced increasing confidence in her ability to learn Italian over the year. At the beginning. Anuradha described a sense of failure in relation to her attempts to learn Italian: 'I feel really bad at it. [...] I just can never remember it.' By the summer, Anuradha recognised that living in Rome would give her opportunities to learn Italian, and expressed confidence she would learn it successfully as her father had done: '[My dad learnt Italian] in Italy. [...] If my dad can do it, why can't l?'

While the study does not provide 'hard evidence', it seems likely that the children's participation in the activities played a role in their developing self-understandings. The children's comments about their participation in the activities and the shifts in the self-representations of some of the children through the activities indicate that that imaginative and reflective activities such as those used for data collection in this study provide a 'navigational space' (Moje et al., 2004) in which children can make sense of their proficiency in and use of different languages within the diverse social contexts of their lives.

\section{ACKNOWLEDGEMENTS}

I would like to thank the children and teachers who participated in the doctoral study behind this paper and Linda Fisher and Michael Evans (Faculty of Education, University of Cambridge) for their insights and guidance as $\mathrm{PhD}$ supervisor and adviser. 


\section{REFERENCES}

Block, D. (2006) Multilingual Identities in a Global City: London Stories. London: Palgrave.

Block, D. (2007a) Second Language Identities. London: Continuum.

Block, D. (2007b) 'The rise of identity in SLA research, post Firth and Wagner (1997).' The Modern Language Journal, 91, pp. 863-876. D.O.I.: http://dx.doi.org/10.1111/j.1540-4781.2007.00674.x

Charmaz, K. (1990) '"Discovering" chronic illness: using grounded theory.' Social Science and Medicine, 30, pp. 1161-1172.

D.O.I.: http://dx.doi.org/10.1016/0277-9536(90)90256-R

Clark, A. and Moss, P. (2001) Listening to Young Children: The Mosaic Approach. London: National Children's Bureau for the Joseph Rowntree Foundation.

Connelly, F., \& Clandinin, D. (1990) 'Stories of experience and narrative inquiry.' Educational Researcher, 19, pp. 2-14.

D.O.I.: http://dx.doi.org/10.3102/0013189x019005002

Dornyei, Z. (2007) Research Methods in Applied Linguistics. Oxford:

Oxford University Press.

Levine, R. (2013) Children's Identities as Users of Languages: a Case Study of Nine Key Stage 2 Pupils with a Range of Home Language Profiles. Doctoral Thesis. University of Cambridge.

Moje, E., McIntosh Ciechanowski, K., Kramer, K., Ellis, L., Carrillo, R., \& Collazo, T. (2004). 'Working toward third space in content area literacy: An examination of everyday funds of knowledge and discourse.' Reading Research Quarterly, 39, pp. 38-71.

D.O.I.: http://dx.doi.org/10.1598/RRQ.39.1.4

Norton, B. and Toohey, K. 2011 'Identity, language learning and social change.' Language Teaching, 44, pp. 412-446.

D.O.I.: http://dx.doi.org/10.1017/S0261444811000309

Oaklander, V. (1978) Windows to Our Children: A Gestalt Therapy Approach to Children and Adolescents. Utah: Real People Press.

Stake, R. (1995) The Art of Case Study Research. Thousand Oaks: Sage Publications.

Stake, R. (1998) 'Case Studies.' In Denzin, N. and Lincoln, Y. Strategies of Qualitative Inquiry. London: Sage.

Vidal Rodeiro, C. (2009) Some Issues on the Uptake of Modern Foreign Languages at GCSE: Statistics Report Series No. 10. Cambridge: Cambridge Assessment.

Weedon, C. (1987) Feminist Practice and Poststructuralist Theory. Oxford: Basil Blackwell. 
"Siempre ha estado atrapado en mi interior pero ahora ha salido": exploraciones de las identidades lingüísticas de los niños a través de actividades creativas.

\section{Sobre la autora:}

\section{Ruth Levine \\ leviner@hope.ac.uk}

Having recently completed PhD research into children's identities as users of different languages at the University of Cambridge, Ruth has a keen interest in children with community and heritage languages. She is also committed to the broader field of language education. After teaching languages in schools in Cambridge, Conwy and Villach (Austria), she moved into research and teacher education. Following MEd study, she worked as a researcher on a government-funded study looking at language learning at Key Stage 3. Alongside PhD study, Ruth developed a one month intercultural programme for language teachers and trainees in China and has delivered this in the UK and in China. She is currently working in teacher education at Liverpool Hope University where she contributes to primary and secondary programmes

\section{Para citar este artículo:}

Levine, R. (2014). "Siempre ha estado atrapado en mi interior pero ahora ha salido": exploraciones de los niños de sus identidades lingüísticas a través de actividades creativas. Revista Fuentes, 15, Junio,

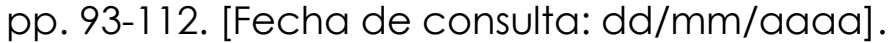

http://www.revistafuentes.es/

D.O.I.: http://dx.doi.org/10.12795/revistafuentes.2014.i15.05 